\title{
The assessment of morning anxiety before different otorhinolaryngological surgical procedures
}

\section{Farklı kulak burun boğaz ameliyatları öncesi sabah anksiyetesinin değerlendirilmesi}

\author{
Murat Bınar(D), Burak Aşık (D), Hakan Genç®D \\ Department of Otolaryngology, SBÜ Gülhane Training and Research Hospital, Ankara, Turkey
}

\begin{abstract}
Objectives: This study investigated preoperative anxiety on the morning of surgery and whether or not different anxiety levels for different surgeries occurred in patients undergoing otorhinolaryngology surgeries.
\end{abstract}

Patients and Methods: A total of 186 individuals including 162 patients and 24 controls were included in the study. The consecutive patients scheduled for surgery were requested to complete a State-Trait Anxiety Inventory (STAI) form on the morning of surgery. The study population was divided into five groups according to the major headings of planned surgical procedure: (i) rhinology, (ii) otology, (iii) head and neck surgery, (iv) general otolaryngology, and $(v)$ control group. Total anxiety scores were compared and each item of the STAI form was specifically analyzed.

Results: According to the analysis of total scores from the STAI-State (S) and the STAI-Trait (T), there was no significant difference in the level of anxiety among the surgery groups. Additionally, we could not find any difference between any of the surgery groups and the control group. When the specific item analysis was performed, 13 (65\%) of the total 20 items of the STAI-S form were significantly different among the groups, and patients who underwent head and neck surgery showed more preoperative anxiety than those undergoing other surgical interventions $(\mathrm{p}<0.05)$.

Conclusion: Different surgical procedures may cause different levels of anxiety. The clinical staff should consider the outcomes of this study during the preparation and management of patients undergoing otorhinolaryngological surgeries.

Keywords: Anxiety; informed consent; otolaryngology; surgical procedures.

\section{$\ddot{O} Z$}

Amaç: Bu çalışmada kulak burun boğaz ameliyatı olacak hastalarda ameliyat günü sabahı ameliyat öncesi anksiyete ve farklı ameliyatlar için farklı kaygı düzeylerinin gelişip gelişmediği araştırıldı.

Hastalar ve Yöntemler: Çalışmaya 162 hasta ve 24 kontrol olmak üzere toplam 186 birey alındı. Ameliyat planlanan sıralı hastalardan, ameliyat sabahında Durumluk-Sürekli Kaygı Envanterini (STAI) doldurmaları istendi. Çalışma popülasyonu planlanan cerrahi işlemlerin ana başlıklarına göre beş gruba ayrıldı: (i) rinoloji, (ii) otoloji, (iii) baş-boyun cerrahisi, (iv) genel kulak burun boğaz ve $(v)$ kontrol grubu. Toplam anksiyete puanları karşılaştırıldı ve STAI formundaki her bir madde özel olarak analiz edildi.

Bulgular: STAI-Durumluk (S) ve STAI-Sürekli (T) formlarının toplam puanlarının analizine göre, cerrahi gruplar arasında anksiyete düzeylerinde anlamlı bir fark yoktu. Ayrıca, herhangi bir cerrahi grubu ile kontrol grubu arasında anlamlı bir fark bulunamadı. Spesifik madde analizi yapıldığında ise, STAI-S formundaki toplam 20 maddeden 13'ü (\%65) gruplar arasında anlamlı olarak farklıydı ve baş-boyun cerrahisi geçirecek hastaların diğer cerrahi girişimlere göre daha fazla ameliyat öncesi anksiyete yaşadığını gösterdi $(\mathrm{p}<0.05)$.

Sonuç: Farklı cerrahi işlemler farklı anksiyete seviyelerine neden olabilmektedir. Klinik personeli, kulak burun boğaz ameliyatı olacak hastaların hazırlanması ve yönetimi sırasında bu çalışmanın sonuçlarını dikkate almalıdır.

Anahtar sözcükler: Anksiyete; aydınlatılmış onam; kulak burun boğaz; cerrahi işlemler.

Received: May 07, 2018 Accepted: June 26, 2018

Correspondence: Murat Bınar, MD. SBÜ Gülhane Eğitim ve Araştırma Hastanesi Kulak Burun Boğaz Kliniği, 06010 Etlik, Ankara, Turkey. Tel: 0312 - 3045707 e-mail: mbinar4@yahoo.com 
Otorhinolaryngological surgeries are frequently performed throughout all regions of the world, therefore, preoperative anxiety surrounding Ear, Nose and Throat (ENT) surgeries affect a large portion of patients. While describing the surgical procedure that is deemed appropriate for the patient, the risks and complications associated with the procedure are described in detail using informed consent. Some of the patients may refuse to be operated immediately after hearing the process described to them, and some may spend a while thinking. In contrast, some patients easily agree to the recommended surgery. When patients visit the doctor to describe their complaints and find a solution to their disease, they may experience a different mood immediately after recommendation of surgery. The level of anxiety experienced by patients on the morning of surgery may also differ according to the planned surgical procedure.

This study aimed to evaluate preoperative anxiety which may be caused by the surgical procedure, surgical risks, and complications in patients undergoing ENT surgery for the first time. Furthermore, different levels of anxiety for different surgical procedures have been attempted to be understood. By doing so, we also aimed to provide a positive effect on the approach of the health staff, especially doctors and nurses, to the patients' mood, by understanding the anxiety experienced by patients undergoing surgery.

\section{PATIENTS AND METHODS}

\section{Subjects}

The Local Ethics Committee approved the study protocol. The study was conducted in accordance with the principles of the Declaration of Helsinki. A total of 186 consecutive subjects (142 males and 44 females; mean age 33.5 years; range 18 to 85 years) were included in the study. There were 162 subjects in the surgery group and 24 were in the control group. Consecutive patients who had already been given indications for otorhinolaryngological surgery were prospectively included in the study on a voluntary basis on the morning of their surgery. The patients were excluded if they (i) had an ENT surgery previously, (ii) had psychiatric disorders, (iii) had a history of drug use for psychiatric reasons, and (iv) were aged $<18$ years. All subjects were evaluated with a review of history and a detailed physical examination once again on the morning of surgery. All possible risks and complications of the surgical procedures were explained in detail. The patients read the written informed consent for each surgical procedure again and signed these forms. Their questions and concerns regarding the surgery were clarified. In case of misunderstandings, any further questions of the patients were also answered. After this conversation, the patients were requested to fill out the State-Trait Anxiety Inventory (STAI) for the purpose of this study. All of these steps were carried out by three surgeons. Patients were divided into five groups according to the planned surgical procedure: (i) rhinology group, (ii) otology group, (iii) head and neck surgery group, (iv) general otolaryngology group, and (v) the control group. The control group consisted of patients who were routinely examined in the department, but were not planned for surgery.

\section{Evaluation of anxiety}

The level of anxiety was assessed using the STAI. ${ }^{[1]}$ There are two separate self-report scales in this inventory measuring two distinct anxiety concepts: state anxiety (STAI-S) and trait anxiety (STAI-T). The STAI-S had 20 statements asking how the patients felt at a particular moment, and the STAI-T had 20 statements asking how they generally felt independent of the current conditions. Each item has four answer choices that are scored from 1-4. The total score is calculated by finding the sum of the 20 items for each inventory. The scores range from 20 to 80 and higher scores indicated more anxiety. There was no time limit for filling out the forms. Each patient completed the forms in approximately five minutes in our department of otolaryngology after they were admitted to the clinic on the morning of surgery. None of the patients had any difficulties in completing the forms. The STAI was previously adapted for the Turkish population and has shown acceptable levels of reliability and validity. ${ }^{[2,3]}$

\section{Statistical analysis}

Statistical analyses were performed using SPSS for Windows version 15.0 (SPSS Inc., Chicago, IL, USA). Mann-Whitney $U$ test was used for the comparison of continuous variables between two groups, and comparisons between more than two groups were assessed with the Kruskal Wallis test. Correlations between variables were explored using the Spearman correlation test. Significance was defined as $\mathrm{p}<0.05$.

\section{RESULTS}

The mean total STAI-S and STAI-T scores in the study population were $43.33 \pm 6.81$ and $44.65 \pm 6.49$, respectively. These values were $42 \pm 6.14$ and $45.29 \pm 4.53$ in the control group. The level of anxiety in the overall study population $(n=162)$ did not differ from that in the control group $(n=24)$ for either the STAI-S or the STAI-T ( $\mathrm{p}=0.206$ and $\mathrm{p}=0.454$, respectively). 
Table 1

The comparison of total anxiety scores between the surgery groups and the control group

\begin{tabular}{|c|c|c|c|c|}
\hline & \multicolumn{2}{|c|}{ STAI-State score } & \multicolumn{2}{|c|}{ STAI-Trait score } \\
\hline & Mean \pm SD & $p$ & Mean \pm SD & $p$ \\
\hline \multicolumn{5}{|l|}{ Surgery groups } \\
\hline Rhinology $(\mathrm{n}=89)$ & $43.70 \pm 6.05$ & 0.178 & $44.69 \pm 4.72$ & 0.301 \\
\hline Otology $(n=32)$ & $42.21 \pm 8.06$ & 0.507 & $44.53 \pm 9.07$ & 0.612 \\
\hline Head and neck $(n=21)$ & $42.90 \pm 8.66$ & 0.298 & $44.85 \pm 8.46$ & 0.819 \\
\hline General otorhinolaryngology $(\mathrm{n}=20)$ & $43.95 \pm 5.92$ & 0.427 & $44.45 \pm 6.61$ & 0.696 \\
\hline
\end{tabular}

The number of subjects in the rhinology, otology, head and neck surgery, general otorhinolaryngology, and control groups were 89, 32, 21, 20, and 24, respectively. The mean total STAI-S scores were $43.70 \pm 6.05,42.21 \pm 8.06,42.90 \pm 8.66,43.95 \pm 5.92$, and $42 \pm 6.14$, respectively. The mean total STAI-T scores were $44.69 \pm 4.72,44.53 \pm 9.07,44.85 \pm 8.46,44.45 \pm 6.61$, and $45.29 \pm 4.53$, respectively. The analysis of total STAI-S and STAI-T scores showed that there was no significant difference in the level of anxiety among the surgery groups $(p=0.921$ and $p=0.715)$. In addition, we did not find any difference between any of the surgery

Table 2

The comparison of specific items (significantly differed) among the groups

\begin{tabular}{|c|c|c|c|c|c|c|}
\hline & $\begin{array}{c}\text { Rhinology } \\
(\mathrm{n}=89)\end{array}$ & $\begin{array}{l}\text { Otology } \\
(n=32)\end{array}$ & $\begin{array}{l}\text { Head and neck } \\
\qquad(\mathrm{n}=21)\end{array}$ & $\begin{array}{l}\text { General } \\
\text { Otorhinolaryngology }\end{array}$ & $\begin{array}{l}\text { Control } \\
(n=24)\end{array}$ & \\
\hline & Mean \pm SD & Mean \pm SD & Mean \pm SD & Mean \pm SD & $\overline{M e a n} \pm \mathrm{SD}$ & $p$ \\
\hline \multicolumn{7}{|l|}{ STAI-State } \\
\hline \multicolumn{7}{|l|}{ Group } \\
\hline Item-3 & $1.55 \pm 0.70$ & $1.53 \pm 0.80$ & $2.05 \pm 0.97$ & $1.95 \pm 1.00$ & $1.25 \pm 0.53$ & 0.009 \\
\hline Item-4 & $1.12 \pm 0.42$ & $1.19 \pm 0.47$ & $1.67 \pm 1.02$ & $1.30 \pm 0.57$ & $1.13 \pm 0.45$ & 0.007 \\
\hline Item-6 & $1.61 \pm 0.85$ & $2.03 \pm 0.97$ & $2.24 \pm 0.94$ & $2.25 \pm 1.12$ & $1.58 \pm 0.78$ & 0.003 \\
\hline Item-7 & $1.44 \pm 0.67$ & $1.63 \pm 0.55$ & $2.00 \pm 0.89$ & $1.90 \pm 0.97$ & $1.42 \pm 0.72$ & 0.006 \\
\hline Item-9 & $1.58 \pm 0.76$ & $1.75 \pm 0.84$ & $2.19 \pm 1.08$ & $2.00 \pm 1.08$ & $1.42 \pm 0.50$ & 0.036 \\
\hline Item-12 & $1.21 \pm 0.53$ & $1.28 \pm 0.58$ & $1.76 \pm 0.77$ & $1.80 \pm 0.95$ & $1.21 \pm 0.66$ & $<0.001$ \\
\hline Item-13 & $1.14 \pm 0.46$ & $1.25 \pm 0.67$ & $1.62 \pm 0.80$ & $1.70 \pm 0.92$ & $1.29 \pm 0.62$ & $<0.001$ \\
\hline Item-14 & $1.21 \pm 0.53$ & $1.31 \pm 0.54$ & $1.67 \pm 0.86$ & $1.55 \pm 0.83$ & $1.21 \pm 0.41$ & 0.023 \\
\hline Item-15 & $2.91 \pm 0.84$ & $2.72 \pm 1.05$ & $1.95 \pm 0.92$ & $2.25 \pm 1.07$ & $2.88 \pm 0.68$ & 0.001 \\
\hline Item-16 & $3.06 \pm 0.90$ & $2.66 \pm 0.94$ & $2.29 \pm 0.90$ & $2.55 \pm 0.83$ & $3.08 \pm 0.78$ & 0.001 \\
\hline Item-17 & $1.40 \pm 0.63$ & $1.59 \pm 0.84$ & $2.29 \pm 1.01$ & $1.90 \pm 0.85$ & $1.58 \pm 0.72$ & $<0.001$ \\
\hline Item-19 & $2.37 \pm 1.07$ & $1.88 \pm 0.94$ & $1.62 \pm 0.74$ & $1.85 \pm 1.04$ & $2.42 \pm 0.83$ & 0.003 \\
\hline Item-20 & $2.94 \pm 0.95$ & $2.53 \pm 1.02$ & $2.05 \pm 0.92$ & $2.50 \pm 0.95$ & $2.88 \pm 0.68$ & 0.002 \\
\hline \multicolumn{7}{|l|}{ STAI-Trait } \\
\hline \multicolumn{7}{|l|}{ Group } \\
\hline Item-30 & $3.11 \pm 0.61$ & $2.69 \pm 0.90$ & $2.86 \pm 0.65$ & $2.75 \pm 0.79$ & $3.04 \pm 0.62$ & 0.048 \\
\hline Item-40 & $1.62 \pm 0.76$ & $1.94 \pm 0.84$ & $2.10 \pm 0.94$ & $1.95 \pm 1.00$ & $2.00 \pm 0.72$ & 0.024 \\
\hline
\end{tabular}



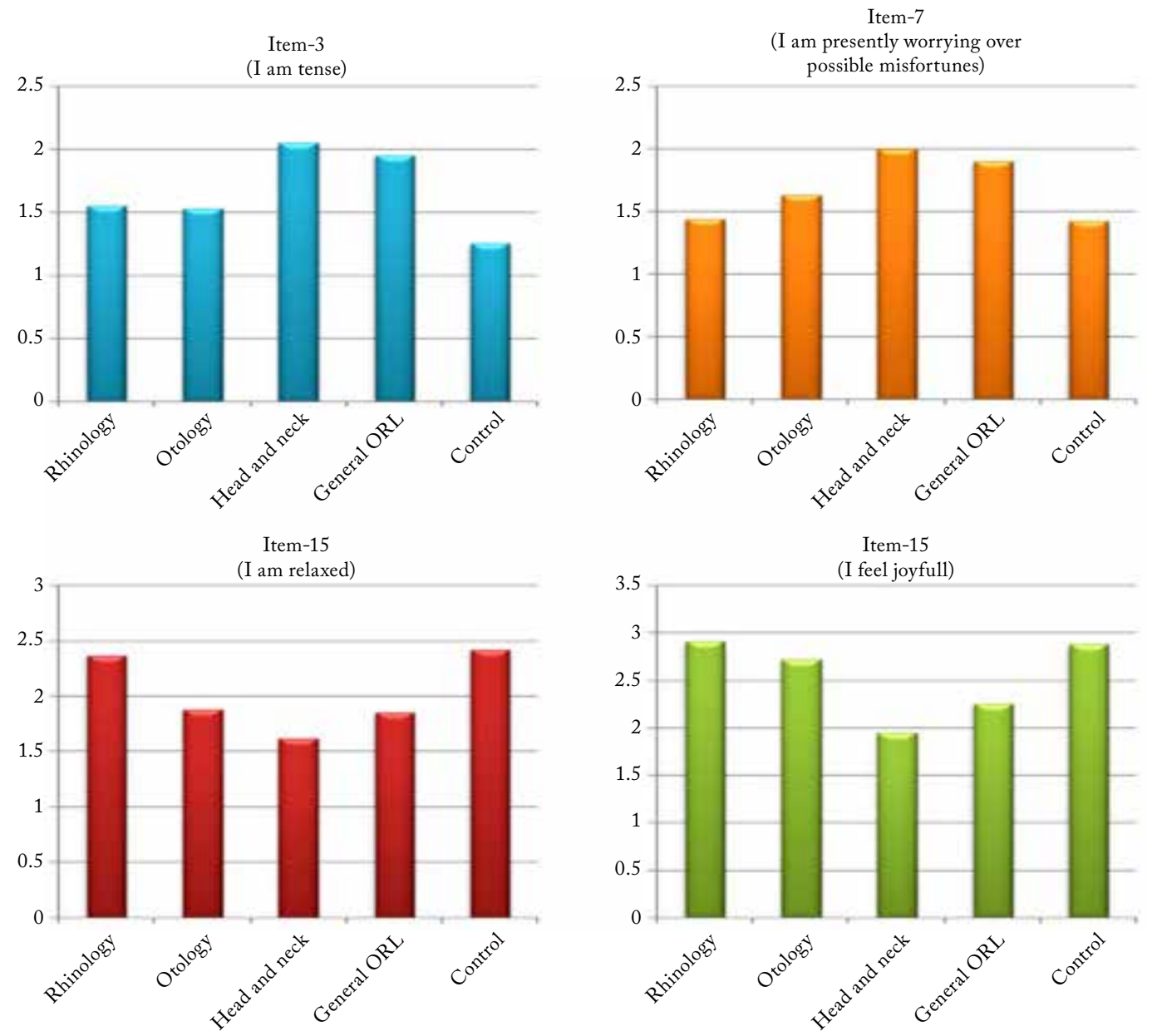

Figure 1. The outcomes from the analysis of some of the significantly differed specific items in the State-Trait Anxiety Inventory-State. First two are negatively worded and the other two are positively worded. ORL: Otorhinolaryngology.

groups and the control group when the total STAI scores were compared (Table 1).

After aforementioned total calculation, each item in the STAI-S and the STAI-T forms were analyzed. Of the total 20 items in the STAI-S form, $13(65 \%)$ were significantly different among the groups (Table 2, Figure, 1). For the STAI-T form, significant difference was found in only two items (10\%) (Table 2).

When we examined the effect of gender difference on anxiety in overall study population, we have found that male patients $(n=128)$ gave significantly higher STAI-S scores than female patients $(n=34)(p=0.002)$. This difference was not significant for the STAI-T forms ( $\mathrm{p}=0.262$ ). Among the four surgery groups, the only significant difference was observed in the rhinology group. The male patients in the rhinology group gave higher anxiety scores in the STAI-S form than the female patients $(p=0.008)$. Except for this significant finding, no other gender difference was recognized in the other surgery groups.

Correlation analysis showed that the STAI-S and the STAI-T scores were positively correlated in overall study population $(p=0.001, r=0.25)$. There was no significant correlation between the other parameters such as age, gender, and surgical groups.

\section{DISCUSSION}

Anxiety is caused by an identification of danger, either internally or externally. ${ }^{[4]}$ Preoperative anxiety arises from the fear and concerns of the patient related to the planned surgery and its complications. ${ }^{[5,6]}$ The severity of anxiety may vary even among patients who will undergo the same surgery. Many factors can affect the severity of anxiety such as the surgeon, surgical procedure, risks of surgery, the duration of surgery, etc. Even the mood of surgeon may affect the patient's anxiety at the time 
of explanation of informed consent. The anxiety level of patients may change in time after they leave the doctor; patients begin to investigate information about the surgery and related complications before they accept the surgery. However, for the planned surgery, patients prepare themselves to be ready for the surgery; some can succeed, but some cannot. The waiting period until the day of surgery may affect the level of anxiety. If there is any level of anxiety, it may increase as the day of surgery approaches. Badner et al. ${ }^{[7]}$ investigated whether there was a correlation between level of anxiety on the night before surgery and immediately preoperatively. They found that anxiety remained constant from the afternoon before surgery to the immediate preoperative period. On the other hand, patients always have the option to refuse surgery, and this may totally eliminate the anxiety until their next acceptation of surgery. As patients learn about solutions for possible problems, their anxiety degree may reduce. According to Moerman et al., ${ }^{[8]}$ patients with a high need for information also had a high level of anxiety. Preoperative patient education was shown to be effective in reducing preoperative anxiety in patients scheduled for surgery. ${ }^{[9,10]}$

The design of the present study was completely different from previous reports because it mainly focused on preoperative morning anxiety caused by different otorhinolaryngologic surgical procedures. Aforementioned factors gave rise to the question how patients feel on the morning of ENT surgeries. Therefore, we aimed to reveal how the level of anxiety varies according to different ENT surgeries on the morning of surgery.

The results of this study showed that there was no significant difference among the patients undergoing different ENT surgeries, according to the total STAI scores. However, the subanalysis of specific items demonstrated that patients undergoing head and neck surgeries experienced more preoperative anxiety compared to those undergoing rhinologic, otologic, and general otorhinolaryngological surgeries. The head and neck groups consisted of patients planned for mostly tumor resection, biopsies, and reconstruction surgeries. The patients' most frequently asked questions were related to neurovascular complications, airway problems, and postoperative quality of life, which were the leading concerns for those undergoing head and neck surgeries. Most of the previous studies mainly investigated the preoperative anxiety due to rhinologic surgeries. ${ }^{[11-13]}$ However, when various surgical interventions of ENT were evaluated as in our study, we see that patients are more likely to be anxious about head and neck surgeries. In contrast, patients undergoing head and neck surgeries were less relaxed and less pleasant compared to rhinologic and otologic surgeries, according to the "positively worded" items analysis.

The null hypothesis of this study supports the idea that different ENT surgeries cause different levels of anxiety. However, the results from total STAI scores showed that there was no difference in terms of level of anxiety among the surgery groups or between the surgery groups and the control group. When patients were asked to verbally explain their feelings before surgery, they usually stated they were excited and nervous. However, the evaluation of total scores did not support this judgment. This is most probably the result of presence of both positively worded and negatively worded items in the same inventory. The STAI-S form contains 10 positively and 10 negatively worded items. The reason why total scores did not differ among the surgery groups could be best explained by the fact that lower scores and higher scores in the STAI-S were balanced. However, the specific item analysis showed that $65 \%$ of the items in the STAI-S form were significantly different among the groups. The rate of significantly different items in the STAI-T form was only $10 \%$. The STAI-S, used to show how the patients feel at a particular moment, is accepted as the gold standard for the assessment of preoperative anxiety in the literature ${ }^{[10,14]}$ which is why we chose this inventory for the purpose of this study.

Domar et al. ${ }^{[15]}$ found that the mean anxiety score measured by STAI was 45 in their study population consisting of 523 patients whose preoperative anxiety levels were investigated. They also found that female patients were more anxious than male patients. The studies by Badner et al. ${ }^{[7]}$ and Moerman et al. ${ }^{[8]}$ support this gender difference in the same manner. In our study population $(\mathrm{n}=162)$, the mean total STAI-S and STAI-T scores were 43.33 and 44.65 , which were similar to previous studies. However, male patients had higher STAI-S scores than female patients in our study. Moreover, the male patients in the rhinology group gave higher anxiety scores in the STAI-S form than the female patients did $(p=0.008)$. Compared to the previous studies, these results were surprising. Another study investigating preoperative anxiety in patients undergoing endoscopic sinus surgery demonstrated that female gender, bad preoperative mood, and gathering of additional information from friends were associated with increased preoperative anxiety. ${ }^{[16]}$

The sample size for each group ranged variously, and this could be considered a limitation of the study. However, patients were consecutively included in this study, therefore, it is an expected result that the number of rhinologic surgeries was leading in overall study population. The presence of three different doctors who 
explained the surgical procedures on the surgery day, independent of primary surgeon of the patient, may have caused "different doctor effect" on the patients' mood, which may have lead to different levels of anxiety. However, all three authors who performed this study agreed with each other before the start of the study to use the same explanation style for each surgical procedure. This method also gave patients the chance to ask further questions related to their surgery. We believe that this working design would reduce the aforementioned bias.

In conclusion this study showed that different surgical procedures in ENT practice may cause different levels of preoperative anxiety. Doctors and clinical staff should be aware that patients to be operated in ENT clinics have different emotional conditions when they are admitted the hospital on the day of surgery. The management of patients has to be adjusted in positive manner in such conditions.

\section{Declaration of conflicting interests}

The authors declared no conflicts of interest with respect to the authorship and/or publication of this article.

\section{Funding}

The authors received no financial support for the research and/or authorship of this article.

\section{REFERENCES}

1. Spielberger CD, Gorsuch RL, Lushene RE. Manual for State-Trait Anxiety Inventory. Palo Alto, California: Consulting Psychologist Pres; 1970.

2. Tunay S, Soygüt G. The reliability and validity of Turkish Brief Measure of Worry Severity based on Turkish university students. [Article in Turkish] Turk Psikiyatri Derg 2009;20:68-74.

3. Öner N, Le Compte A. Durumluk Sürekli Anksiyete Envanteri E1 Kitab1. İstanbul: Boğaziçi Üniversitesi
Yayınları; 1985.

4. Lohr JM, Olatunji BO, Sawchuk CN. A functional analysis of danger and safety signals in anxiety disorders. Clin Psychol Rev 2007;27:114-26.

5. Ramirez DA, Brodie FL, Rose-Nussbaumer J, Ramanathan S. Anxiety in patients undergoing cataract surgery: a pre- and postoperative comparison. Clin Ophthalmol 2017;11:1979-1986.

6. Erol Y, Çakan A, Ergönül AG, Sertöz Ö, Özdil A, Turhan K, et al. Psychiatric assessments in patients operated on due to lung cancer. Asian Cardiovasc Thorac Ann 2017;25:518-521.

7. Badner NH, Nielson WR, Munk S, Kwiatkowska C, Gelb AW. Preoperative anxiety: detection and contributing factors. Can J Anaesth 1990;37:444-7.

8. Moerman N, van Dam FS, Muller MJ, Oosting H. The Amsterdam Preoperative Anxiety and Information Scale (APAIS). Anesth Analg 1996;82:445-51.

9. Ayyadhah Alanazi A. Reducing anxiety in preoperative patients: a systematic review. Br J Nurs 2014-23;23:387-93.

10. Taşdemir A, Erakgün A, DenizMN, Çertuğ A. Comparison of Preoperative and postoperative anxiety levels with statetrait anxiety inventory test in preoperatively informed patients. Turk J Anaesth Reanim 2013;41:44-9.

11. Sari K, Gul AI, Kantekin Y, Karaaslan O, Gencer ZK. Transseptal Suturing Reduce Patient Anxiety after Septoplasty Compared to Nasal Packing. Acta Medica (Hradec Kralove) 2016;59:133-6.

12. Ocalan R, Akin C, Disli ZK, Kilinc T, Ozlugedik S. Preoperative anxiety and postoperative pain in patients undergoing septoplasty. B-ENT 2015;11:19-23.

13. Sahin C, Aras HI. Effect on patient anxiety of lidocaine infiltration into nasal packing after septoplasty: prospective, controlled study. J Laryngol Otol 2015;129:784-7.

14. Tenenbaum G, Furst D, Weingarten G. A statistical reevaluation of the STAI anxiety questionnaire. J Clin Psychol 1985;41:239-44.

15. Domar AD, Everett LL, Keller MG. Preoperative anxiety: is it a predictable entity? Anesth Analg 1989;69:763-7.

16. Hosemann W, Loew TH, Forster M, Kühnel T, Beule AG. Perioperative pain and anxiety in endoscopic sinus surgery. Laryngorhinootologie 2011;90:476-80. 